\title{
A DESINFORMAÇÃO NA AGENDA PÚBLICA DO PARLAMENTO: AS ESTRATÉGIAS DO SENADO FEDERAL CONTRA AS NOTÍCIAS FALSAS
}

\author{
THE DISINFORMATION IN PARLIAMENT'S PUBLIC AGENDA: \\ THE FEDERAL SENATE STRATEGIES AGAINST FAKE NEWS
}

\author{
DESINFORMACIÓN EN LA AGENDA PÚBLICA DEL PARLAMENTO: \\ ESTRATEGIAS DEL SENADO FEDERAL CONTRA NOTICIAS FALSAS
}

\author{
Michel Carvalho da Silva*
}

\begin{abstract}
Resumo: Analisa-se o tratamento conferido pelo Senado Federal à questão da desinformação, discutindo como uma demanda social se torna um problema público, que exige uma ação do Estado. Nesse sentido, o Senado dá visibilidade à discussão em torno da necessidade de políticas públicas para lidar com os efeitos da propagação de conteúdos falsos. O trabalho mostra que as estratégias do Senado adotadas nas esferas institucional/comunicacional e legislativa buscam fortalecer a imagem pública do parlamento. No entanto, verifica-se que um problema social, como o da desinformação, não pode ser resolvido com ações açodadas e meramente midiáticas. $\mathrm{O}$ combate às informações falsas exige medidas amplas e efetivas, que contem com a participação dos diferentes setores da sociedade civil.
\end{abstract}

Palavra-chave: desinformação, agenda, comunicação legislativa, políticas públicas, visibilidade.

Abstract: It analyzes the treatment given by the Federal Senate to the issue of disinformation, discussing how a social demand becomes a public problem, which requires action by the State. This Legislative House gives visibility to the discussion around the need for public policies to deal with the effects of the spread of false content. The work shows that the Senate strategies adopted in the institutional / communicational and legislative spheres seek to strengthen the image of this parliament with the population. However, it appears that a social problem, such as that of disinformation, cannot be solved with timely and merely mediatic actions. The fight against false information requires broad and effective measures, with the participation of different sectors of civil society.

Keywords: disinformation, schedule, legislative communication, public policy, visibility.

Resumen: Analiza el tratamiento dado por el Senado Federal a la cuestión de la desinformación, discutiendo cómo una demanda social se convierte en un problema público, que requiere la acción del Estado. Esta Cámara Legislativa da visibilidad a la discusión sobre la necesidad de políticas públicas para hacer frente a los efectos de la difusión de contenido falso. El trabajo muestra que las estrategias del Senado adoptadas en las esferas institucional / comunicacional y legislativa buscan fortalecer la imagen de este parlamento con la población. Sin embargo, parece que un problema social, como el de la desinformación, no puede resolverse con acciones oportunas y meramente mediáticas. La lucha contra la información falsa requiere medidas amplias y efectivas, con la participación de diferentes sectores de la sociedad civil.

Palabras clave: desinformación, horario, comunicación legislativa, políticas públicas, visibilidad.

*Doutorando em Ciências Humanas e Sociais (UFABC). Mestre em Ciências da Comunicação (ECA/USP). Integrante do Grupo de Pesquisa Mediações Educomunicativas (MECOM). É Chefe de Serviços de Comunicação Social na Câmara Municipal de Cubatão (SP). E-mail: midiacidada@gmail.com. ORCID iD: https://orcid.org/0000$\underline{0001-8635-136 X}$ 


\section{Introdução}

A pesquisa nacional "Redes Sociais, Notícias Falsas e Privacidade na Internet"1, realizada pelo DataSenado em parceria com as Ouvidorias da Câmara dos Deputados e do Senado Federal, mostrou que aproximadamente oito em cada dez entrevistados já identificou notícia falsa nos sites de redes sociais (SRS), e a maioria (82\%) também afirma verificar se uma notícia é verdadeira antes de compartilhá-la. No entanto, o mais preocupante, de acordo com o estudo, é que quase metade dos entrevistados (47\%) considera ser difícil identificar a veracidade das informações recebidas. Se as pessoas têm dificuldade em verificar se determinado conteúdo na web é falso ou não, imagine um vídeo bem editado, com entonação e tom de voz muito parecidos com o de uma pessoa real, como no caso das deepfakes (CHESNEY; CITRON, 2018).

As eleições brasileiras de 2018 foram marcadas pela distribuição deliberada de conteúdo inverídico nos sites de redes sociais (SRS). De mamadeira erótica a kit-gay, passando pela ameaça de extinção do programa Bolsa-Família até a manipulação das urnas eletrônicas (GRAGNANI, 2018). Na ocasião, o jornal Folha de S. Paulo publicou uma reportagem sobre um suposto esquema em que aliados de um candidato presidencial compraram irregularmente pacotes massivos de envio de mensagens pelo WhatsApp com o objetivo de atingir seu adversário com diferentes informações falsas (fake news) - (MELLO, 2018).

Longe de ser um fenômeno local, a distribuição viral de boatos, rumores e informações falseadas na web já tinha demonstrado seus efeitos nas eleições presidenciais de 2016 nos Estados Unidos, no referendo do Brexit do Reino Unido em outros países. No Brasil, alguns episódios, como a multiplicação de fake news sobre a execução da vereadora Marielle Franco (PSOL) e a greve dos caminhoneiros, deram uma amostra da velocidade de difusão desse conteúdo inverídico e de seu potencial danoso para o debate público. O uso desse expediente tem mostrado capacidade de convencimento, a ponto de estabelecer consensos, mesmo quando fraudes informativas são desmentidas pela mídia tradicional.

Não é só no campo político que a desinformação traz uma série de prejuízos. Informações equivocadas podem gerar comportamentos e atitudes geradores de risco em relação à saúde, seja pela indução de medicamentos inadequados, a adoção de tratamentos sem nenhuma eficácia ou a recusa de medidas protetivas. Recentemente, boatos sobre a vacina da febre amarela se espalharam pelas SRS, o que acabou comprometendo diretamente as metas de imunização do Ministério da Saúde.

\footnotetext{
${ }^{1}$ Foram entrevistados 2,4 mil cidadãos que têm acesso à internet, por meio de ligações para telefones fixos e móveis, no período de 17 a 31 de outubro de 2019. A margem de erro é de dois pontos percentuais, com nível de confiança de 95\% (BRASIL, 2019a).
} 
Com a desintermediação comunicacional e a autocomunicação (CASTELLS, 2019), a difusão de informações falsas, distorcidas ou incompletas sobre os mais variados temas alcançou uma dinâmica incontrolável. Simulando veracidade e apelando à emoção, as fake news operam como atalhos informacionais pelos quais a sociedade cria sentido para a realidade e forma seus esquemas interpretativos. O problema é que esses conteúdos acabam deseducando e desinformando o cidadão em assuntos importantes, como saúde, economia, segurança pública, direitos humanos e política. Desse modo, a desinformação funciona como instrumento de manipulação da opinião pública e, muitas vezes, de propagação de discursos de ódio.

A difusão de mentiras é um fenômeno histórico empregado desde o século XIX (DARNTON, 2017), mas com a onipresença das SRS no cotidiano das pessoas, seu impacto ganha uma outra dimensão (FERRARI, 2018). Diante desse cenário de desinformação, em que fatos objetivos são menos influentes em formar a opinião pública do que apelos às crenças pessoais, o que governos e parlamentos podem fazer para combater a distribuição deliberada de conteúdo inverídico? A partir desta premissa, nos concentraremos nas estratégias adotadas pelo Senado Federal contra as fake news.

Em 2019, o Senado intensificou o debate em torno do problema da desinformação. Foram realizadas audiências públicas ${ }^{2}$ pela Comissão de Direitos Humanos e Legislação Participativa $(\mathrm{CDH})$ do Senado sobre a influência das notícias falsas na sociedade. Além disso, foi criada a Comissão Parlamentar Mista de Inquérito (CPMI) mista das fake news, para investigar ataques cibernéticos contra a democracia e o debate público, uso de perfis falsos nas eleições de 2018, ciberbullying sobre agentes públicos e internautas vulneráveis, e aliciamento de crianças para crimes de ódio.

O Senado também lançou em junho de 2019 uma campanha institucional contra a propagação de fake news, tendo como slogan: "Notícia falsa se combate com boa informação". Por meio das mídias legislativas ${ }^{3}$ da Casa, a iniciativa apresenta dois objetivos principais: mostrar como reconhecer uma informação falsa sobre o Congresso Nacional e como o cidadão pode ajudar a impedir que uma notícia inverídica se espalhe. Na esfera legislativa, o Senado também tenta combater a criação e o compartilhamento de informações falsas, propondo projetos que estabelecem penalidades para quem divulgar fake news.

\footnotetext{
${ }^{2}$ Em $1^{\circ}$ de abril de 2019, a CDH discutiu a influência das fake news na sociedade, contando com a presença de representantes do Intervozes, Safernet, Associação Brasileira Emissora de Rádio e TV (Abert), Instituto Alana, Google Brasil, Facebook e Twitter. Já na audiência pública do dia 04 de julho de 2019, participaram representantes da Abert, Câmara dos Deputados, Federação Nacional dos Jornalistas (Fenaj), Associação Brasileira de Imprensa (ABI), Fórum Nacional pela Democratização da Comunicação (FNDC), Repórteres sem Fronteiras, ONG Artigo 19, e Senado Federal.

${ }^{3}$ São veículos e redes sociais do Senado: Jornal do Senado, Portal Senado Notícias, Rádio Senado, TV Senado, twitter.com/SenadoFederal, twitter.com/RadioSenado, twitter.com/tvsenado, www.instagram.com/senadofederal, $\underline{\text { www.facebook.com/SenadoFederal, www.facebook.com/RadioSenado e www.facebook.com/TVSenado. }}$.
} 
Diante dessa tomada de posição do Senado em relação à questão da desinformação, o artigo, numa abordagem crítico-compreensiva, propõe uma discussão acerca de como o parlamento, enquanto arena de discussão pública e esfera decisória, enquadra determinado problema social em sua agenda, dando-lhe tratamento político. A ideia é refletir como a disseminação de conteúdo inverídico emerge na pauta legislativa, a ponto de o Senado propor debates com diferentes atores políticos e contribuir, assim, com o processo de formulação de políticas públicas contra as fake news.

O artigo está organizado da seguinte maneira: no tópico a seguir um panorama geral sobre o contexto da desinformação, pensando as definições do termo e os desdobramentos desse fenômeno para a democracia e a discussão das políticas públicas. Em seguida, propomos uma reflexão, dentro do paradigma das políticas públicas, sobre problema público, comunicação e agenda. Por fim, discutiremos o enquadramento das notícias falsas como problema público a partir do tratamento dado pelo Senado, refletindo sobre as ações (institucionais e legislativas) deste parlamento sobre o tema em questão.

\section{Desinformação como problema público: conceitos e dimensões}

A história brasileira coleciona episódios em que reputações foram destruídas em virtude da propagação de mentiras, rumores ou boatos, como o caso da Escola Base em 1994, em que os proprietários de um colégio foram acusados injustamente de abuso sexual de crianças (RIBEIRO, 2000). No entanto, a desinformação ganha novos contornos a partir da produção amadora e deliberada de fake news no ecossistema digital. Para se ter uma ideia da gravidade do tema, em 2014, Fabiane Maria de Jesus, foi espancada até a morte por moradores de Guarujá (SP), onde morava. Na ocasião, uma página no Facebook divulgou uma notícia falsa sobre a mulher, acusando-a de praticar magia negra com crianças.

Não existe consenso entre os teóricos do campo a comunicação acerca do termo "fake news". Alguns defendem o uso deste conceito, popularizado durante as eleições norteamericanas de 2016, pois foi incorporado à semântica política e à cobertura jornalística; outros consideram a denominação imprecisa, uma vez que se confunde com outros tipos de desinformação, como exageros, omissões, especulações, notícias mal apuradas e descontextualizadas ou mesmo sátiras. O presente artigo, então, parte da literatura especializada para delimitar conceitualmente a ideia de fake news e apresentar suas múltiplas dimensões.

Allcott e Gentzkow (2017) explicam que fake news são informações comprovadamente falsas, produzidas intencionalmente com o objetivo de influenciar a opinião pública. Os pesquisadores excluem desse grupo os erros de comunicação, rumores, teorias da conspiração, sátiras, declarações falsas de políticos, relatórios inclinados ou enganosos.

Bounegru et al. (2017) pontuam que o significado das fake news não pode ser 
compreendido fora de sua circulação digital. Além da forma ou do conteúdo informativo, as notícias falsas devem ser consideradas em termos de infraestruturas mediadoras, plataformas e culturas participativas que facilitam sua difusão. De acordo com os autores, para serem classificadas como fake news, as informações precisam mobilizar um grande número de leitores, incluindo desde usuários que concordem com o conteúdo disseminado, bem como oponentes para contestar e desmentir as informações publicadas.

Para Vargo, Guo e Amazeen (2017), as fake news estão intrinsecamente ligadas à mídia denominada partidária, ou seja, em muitas questões, as informações falsas em circulação em determinados meios de comunicação correspondem particularmente às agendas de específicos agentes políticos. Outra característica importante na conceituação de fake news é discutida por Aymanns, Foerster e Georg (2017), que apontam que a ausência de base factual nesse tipo de conteúdo não é óbvia, ou seja, a falsidade ou deturpação da mensagem não é clarividente. As notícias falsas para terem algum tipo de efeito sobre o público precisam ser confundidas com dados e informações verídicos.

Por outro lado, existem autores que buscam compreender o problema da difusão de notícias falsas no interior do fenômeno da desordem informacional, em que um conjunto de estratégias comunicacionais são articuladas para minar o funcionamento de instituições (Estado, imprensa, universidades, entre outras) e da cultura democrática ocidental (BENNETT; LIVINGSTON, 2017). Os pesquisadores consideram que esse processo de deslegitimação, que envolve confiança e credibilidade públicas, se aprofunda por conta do esvaziamento de partidos políticos e da própria ideia de representação eleitoral.

Wardle e Derakhsan (2017) explicam que esse universo de desordem informacional engloba diferentes graus e tipos de desinformação, passando pelo falso contexto, falso conteúdo, manipulação, sátira e conteúdo enganoso. Para os pesquisadores, existem três importantes definições para entender esse cenário que circunda as fake news. A misinformation seria a difusão de informação falsa, embora sem intuito de prejudicar. A disinformation envolveria conteúdo sabidamente falso, fabricado ou manipulado com intenção de gerar dano. Já a bad information representaria a disseminação de informações corretas, embora manipuladas com o intuito de prejudicar, como vazamentos, especulações, assédio e discurso de ódio.

A partir desse arcabouço teórico acerca das fake news, defendemos a tese de que as notícias falsas são uma vertente da desinformação. Se os conceitos em torno desse fenômeno comunicacional ainda estão em disputa, não resta dúvida quanto aos efeitos perniciosos da proliferação de conteúdo deliberadamente inverídico. Numa sociedade cada vez mais midiatizada, caracterizada por uma dinâmica de desintermediação, qualquer pessoa com um celular tem a possibilidade de produzir conteúdo viral (MOROZOV, 2018). Se, por um lado, essa mudança possibilita a um número crescente de indivíduos alcançarem visibilidade e poder de agência, sem o auxílio de mediadores; por outro, significa que muitas mensagens, em 
circulação nos SRS, podem ser consumidas como informação verdadeira, mesmo sem nenhum vestígio comprobatório.

A naturalização da mentira e a preferência pela inverdade por parte significativa da população atingiram um patamar inimaginável. Existe uma verdadeira fábrica de fake news em atividade no Brasil e no mundo, que produz e espalha mensagens inverídicas ou distorcidas, utilizando bots, algoritmos e disparos em massa, conforme interesses escusos desses grupos. Esses conteúdos circulam em forma de textos, fotos, vídeos, imagens, memes e outros formatos no WhatsApp, Facebook, Twitter e Youtube. O modus operandi geralmente se baseia na construção de narrativas sobre assuntos controversos ou polêmicos, que possam reforçar preconceitos, prejudicar adversários ou provocar desordem informacional, que abrange desde notícias descontextualizadas ou imprecisas a conteúdos deliberadamente falsos.

Num contexto de polarização política radicalizada (ABRANCHES, 2019), emerge a esfera pública disruptiva, em que posições de centro e moderadas desaparecem, e as pessoas estão dispostas a dialogar somente com quem converge com seu espectro ideológico, tudo o que é contrário a essa concepção de mundo é imediatamente considerado como algo que não merece crédito. Os indivíduos estão criando uma dinâmica na qual elas só enxergam o que elas querem, na qual elas interpretam dados como lhes convêm e compartilham somente aquilo em que acreditam (KEEN, 2012).

O filtro bolha (PARISER, 2012) reforça esse tipo de comportamento polarizado e cria ambiente favorável para pulverização de notícias falsas e o surgimento de discursos de ódio. Sastre, Oliveira e Belda (2018) argumentam que em um cenário altamente dividido entre dois polos ideológicos, se determinado indivíduo demonstra interesse por informações relativas ao lado "A", o processo de "filtro bolha" irá limitar o acesso a informações somente a respeito. Dessa forma, informações sem lastro factual que utilizem esse padrão para a sua difusão terão maior sucesso, já que ele não terá acesso a outras informações que poderiam contrapor ou até esclarecer os fatos. Os SRS, por exemplo, ao se utilizarem a lógica algorítmica para mapear as preferências dos usuários, de modo a personalizar as timelines, criam câmaras de eco que reverberam apenas os pontos de vista intersubjetivos, independentemente de qualquer validação objetiva (FERRARI, 2018).

Outro fator que contribui para pulverização de fake news em escala global é o modelo de negócio baseado no uso de ferramentas de remuneração por meio da conquista de audiência e venda indireta de anúncios. Conforme Sastre, Oliveira e Belda (2018), o conteúdo falso, que geralmente explora temas polêmicos e polarizados, de forma sensacionalista, é compartilhado massivamente em mídias digitais, gerando tráfego em sites e permitindo ganhos financeiros com anúncios por meio do Google AdSense $e^{4}$. Diante desse quadro, observa-se que os SRS lucram

\footnotetext{
${ }^{4}$ Ferramenta gratuita que veicula anúncios em site cadastrados por meio da seleção de temas de interesse e volume de audiência.
} 
com a proliferação de notícias falsas, uma vez que quanto mais notícias compartilhadas, independentemente de sua veracidade, mais receita os anúncios geram as plataformas digitais.

O debate em torno da propagação de notícias falsas enseja uma série de questõeschave, que vão desde a garantia à liberdade de expressão até a responsabilização legal das plataformas digitais no que se refere à difusão de conteúdos deturpados, passando pela criação de leis que penalizem a difusão de conteúdos fraudulentos e de políticas públicas de comunicação que contribuam para um ambiente informacional confiável e diverso.

A seguir discutiremos o processo de definição de agenda pública dentro da esfera parlamentar, a partir da visibilidade midiática de um determinado problema público.

\section{Problema público, comunicação e agenda}

A prática de espalhar boatos ou mentiras acompanha a sociedade há muito tempo, desde a antiguidade, mas com as mídias sociais on-line, esse expediente se tornou um problema público, por afetar o cotidiano de um número significativo de cidadãos e o funcionamento das próprias instituições do Estado. Uma notícia falsa pode provocar o consumo de produtos e serviços, violando o direito fundamental à informação clara e precisa.

A desinformação em saúde tem consequências graves para a gestão pública, como a diminuição da cobertura vacinal ${ }^{5}$ e o reaparecimento de doenças como sarampo e caxumba. A baixa adesão aos procedimentos vacinais e o uso inadequado de medicamentos ou outras substâncias deixa a sociedade em alerta e exige respostas dos atores políticos, que devem pensar em estratégias para ampliar o alcance de campanhas educativas e aperfeiçoar os mecanismos de checagem de informação sobre saúde.

Quando nos referimos a problema público, como o da desinformação, Estado, sociedade e mídia estão implicados no estabelecimento da agenda - definida como o conjunto de assuntos sobre os quais o governo, e pessoas ligadas a ele, concentram sua atenção num determinado momento (KINGDON, 2003). Para o autor, uma questão passa a fazer parte da agenda governamental quando desperta a atenção e o interesse dos formuladores de políticas públicas.

Considerando-se o grande número de acontecimentos existentes no cotidiano, que requer a atenção do Estado, a disputa por atenção é complexa, e deve levar em conta quais problemas são considerados mais ou menos relevantes ao longo do tempo, o que é fundamental para compreender a ação (ou a falta) governamental (CAPELLA, 2013).

A formação de agenda tem relação com os ciclos de visibilidade de determinado problema social. Um desses processos tem relação com o enquadramento dado pelos meios de comunicação ao assunto que exige a ação pública. As temáticas recebem atenção dos governos

\footnotetext{
${ }^{5}$ Para se ter uma ideia, de acordo com dados do Ministério da Saúde, tanto em 2016 quanto em 2017, a cobertura da vacina contra a pólio ficou, pela primeira vez, mais de 10 pontos percentuais abaixo da meta, que é de $95 \%$ : 84,4\%, em 2016; e 83,4\%, em 2017.
} 
quando expostos recorrentemente na mídia. A representação da realidade social construída pelos meios de comunicação nos remete à hipótese da agenda setting, teoria formulada pelos pesquisadores Maxwell McCombs e Donald Shaw nos anos 70, que investiga a importância da mídia como mediadora entre o indivíduo e a realidade da qual se encontra distante.

Como um estudo dos efeitos a longo prazo, a agenda setting redimensiona o grau de influência dos meios de comunicação. O poder de intervir diretamente no comportamento humano, é substituído pela tentativa em hierarquizar e tematizar os assuntos que serão discutidos pelas pessoas no dia a dia. "Ao longo do tempo, os tópicos enfatizados nas notícias tornam-se os assuntos considerados os mais importantes pelo público. A agenda da mídia tornase, em boa medida, a agenda do público" (McCOMBS, 2009, p. 18).

Para Miguel (2002), a mídia tem a capacidade de formular ou reformular as preocupações e demandas sociais, ao trazer à tona aspectos que passam a ser percebidos tanto pela população quanto pelos agentes políticos e servidores públicos, "que se veem na obrigação de dar uma resposta àquelas questões" (MIGUEL, 2002, p. 171). O agendamento midiático cria, então, o clima no qual a informação seria recebida, fixando não só o que vai ser discutido, mas como e por quem.

Se hoje, com a sociedade em rede, não faz sentido falar em efeitos diretos dos veículos jornalísticos sobre a agenda pública, é inegável a capacidade de mobilização da mídia, o que pode ser explicado pelo poder da comunicação em tornar o mundo inteligível para a sociedade. Silverstone (2005) explica que a experiência humana é enriquecida ou empobrecida por imagens e palavras às quais não teríamos acesso sem a presença dos meios de comunicação.

No entanto, a inserção de um tema na agenda da mídia não é automática e os vieses dela resultam, muitas vezes, em uma abordagem não apropriada de questões aos governos (HOWLETT, 2000). Além disso, como observam Penteado e Fortunato (2015), a influência da mídia encontra limites que se estendem desde sua dependência do campo político como fonte de informação, recursos de financiamento e interesses políticos até as ingerências dos anunciantes, que podem interferir na dinâmica de cobertura daquele determinado grupo de comunicação.

Capella (2018) explica que enquanto no campo da comunicação, os estudos sobre a agenda midiática se debruçam sobre o conjunto de questões enfatizadas pela mídia, as pesquisas sobre a agenda pública consideram a importância atribuída pelo público em geral a determinadas questões. Para os formuladores de políticas governamentais, então, a análise sobre agenda deve contemplar questões emergentes na agenda midiática e suas conexões com as agendas pública e de políticas públicas.

Hogwood e Gunn (1984) argumentam que existem outros dois ciclos de visibilidade que interferem no estabelecimento da agenda: o ciclo de "crise", cujos os eventos externos, como guerras, catástrofes naturais ou epidemias, podem iniciar um processo de construção de problema; e o ciclo "político", no qual o início de um problema tem origem no poder de 
mobilização de uma liderança política ou na articulação de segmentos organizados.

Outro aspecto relevante nesse processo é que os problemas públicos são difíceis ou impossíveis de serem resolvidos por meio da ação individual (ANDERSON, 2011) e, por isso, necessitam da intervenção do Estado. No caso da desinformação, existe um consenso em torno da ideia de que é necessário a formulação de políticas públicas para construir um ecossistema informativo equilibrado, mais seguro aos usuários da web.

A formação da agenda é fundamental para o debate público sobre os problemas em tela e a resultante ação governamental, ou seja, a implementação da política pública. Nesse sentido, o Poder Legislativo, como esfera mediadora entre sociedade e governo, se apresenta como espaço privilegiado para definir quais problemas públicos serão enfrentados e quais poderão esperar. O parlamento, como fração de um dos poderes do Estado, tem a função originária de conduzir os debates sobre temas de interesse público, acolhendo as manifestações dos atores sociais envolvidos.

Os problemas públicos são escolhas realizadas por agentes políticos em relação às diversas questões que circulam pela arena pública. Por conta de os parlamentares serem alvo constante de notícias distorcidas ou fraudulentas no ambiente digital, consideramos natural que a temática da desinformação tenha sido privilegiada neste momento na agenda do Senado. No entanto, quando o legislativo prioriza determinados assuntos, acaba ignorando outros, talvez mais relevantes no que se refere ao número de afetados pelo problema social ou pela necessidade de urgência na resolução do mesmo. A agenda política nem sempre coincide com a agenda pública, relacionada ao bem comum e ao conjunto da sociedade.

No caso do enquadramento dado à desinformação pelo Senado, como esquematizado na figura 1, verifica-se que este legislativo identifica a proliferação de conteúdos falsos como um problema público, que afeta o debate público e, consequentemente às decisões políticas. Evidentemente, que ao enquadrar a mencionada questão dentro do paradigma das políticas públicas, o Senado quer influenciar ou, ao menos, participar da elaboração de possíveis soluções para combater a prática da disseminação de mentiras com fins políticos e econômicos. 
Figura 1 - Esquema explicativo sobre como as fake news interferem na dinâmica das políticas públicas.

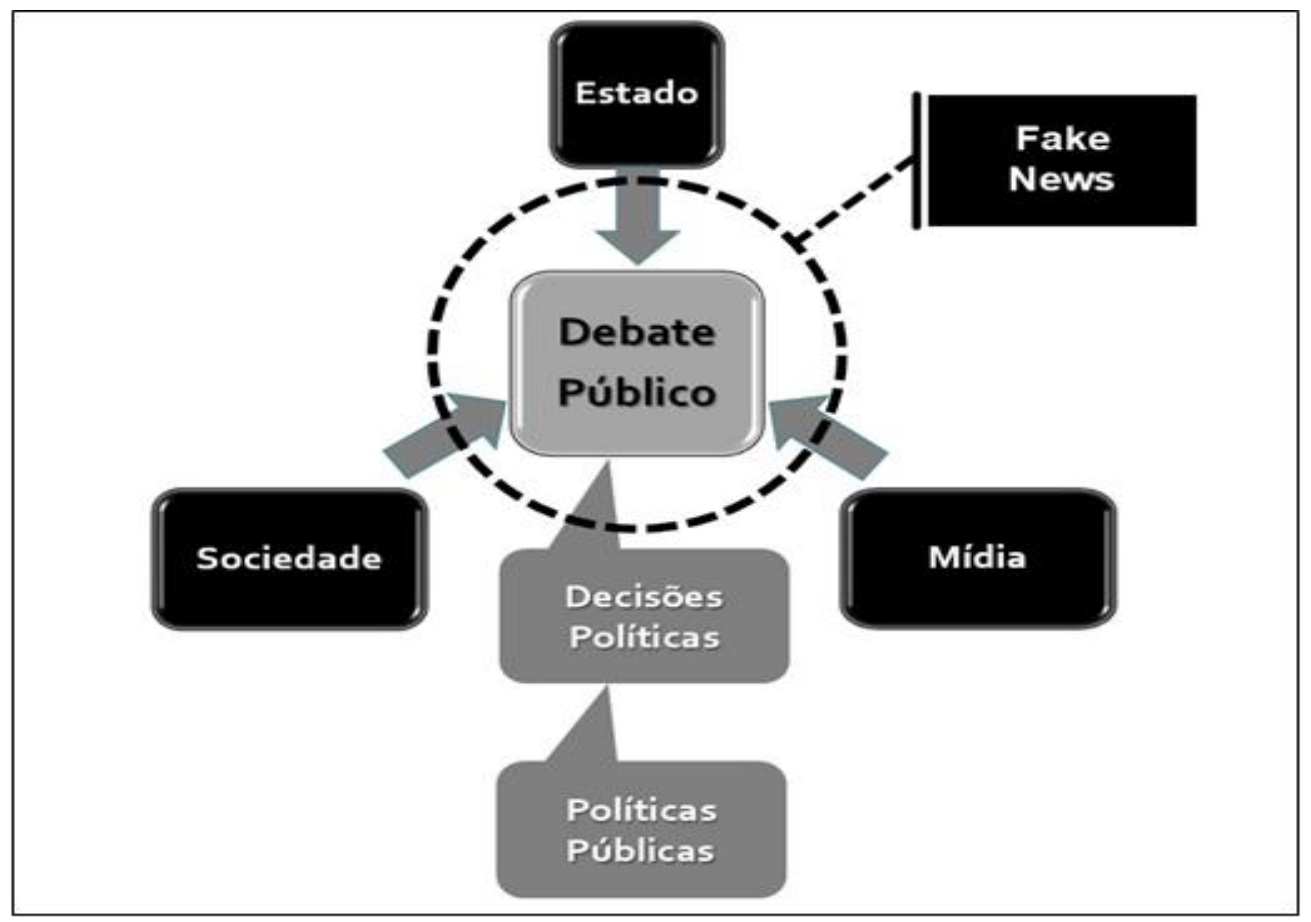

Fonte: Elaborado pelo autor (2020)

Em seguida, discutiremos as estratégias adotadas pelo Senado Federal para combater o problema da desinformação, mas primeiramente iremos apresentar alguns episódios que envolveram este Legislativo com as fake news.

\section{A desinformação na pauta do Senado}

Em levantamento feito junto aos canais de comunicação do Senado, verificamos que este Legislativo, assim como outros órgãos do Poder Público, tem sido alvo recorrente de desinformação. Em 2013, circulou nos SRS uma notícia inverídica de que a senadora na época, Ana Rita (PT-ES), teria criado o projeto que estabelecia a bolsa de R 2 mil mensais para prostitutas (GOMIDE, 2013). O Senado publicou em seus canais de comunicação informações que comprovavam que nunca tramitou proposta com esse teor. Mesmo assim, a notícia falsa ainda circulou por bastante tempos nas mídias digitais

Em 9 agosto de 2017, o Senado chegou a publicar em sua fanpage um post em que negava a existência de um projeto de lei, que que cancelaria automaticamente a carteira de motorista $(\mathrm{CNH})$ depois de trinta dias de vencimento. A publicação menciona que "é fácil checar se uma notícia assim é verdadeira ou falsa", basta o cidadão pesquisar o número da matéria parlamentar no site institucional do Senado e verificar se o tal projeto objeto do boato viralizado existe ou não. 
Já a fanpage da Presidência do Senado divulgou em 5 de março de 2018 uma nota de esclarecimento $^{6}$ que desmentia a informação de que o presidente do Senado da época, o senador Eunício Oliveira (MDB-CE), tinha solicitado a elaboração de um projeto de lei para alterar o Código Penal, a Lei Eleitoral ou o Marco Civil, com o objetivo de criar mecanismos de censura livre manifestação e informação na internet. A publicação ainda mencionava que o senador não havia solicitado ao Conselho de Comunicação do Congresso Nacional, um órgão consultivo e sem a faculdade de apresentar projetos, qualquer sugestão sobre o tema. Naquele período, uma notícia falsa, em circulação nas mídias digitais, afirmava que o Senado estava criando um mecanismo legal para criminalizar quem criticasse os agentes políticos na internet.

Em setembro do ano passado, circulou no aplicativo WhatsApp a informação de que a TV Senado tinha exibido um vídeo sobre o projeto de lei da Câmara $N^{\circ} 27 / 2017$, (conhecido como "Dez Medidas contra a Corrupção"), mas que depois da censura imposta pelo Congresso, o conteúdo havia sido retirado dos canais de comunicação do mencionado parlamento. No entanto, segundo a nota da Secretaria de Comunicação Social do Senado (Secom) divulgada na época, a emissora nunca chegou a veicular o tal vídeo (BRASIL, 2019b).

Por outro lado, o Senado também já foi acusado de propagar desinformação em seus canais de comunicação. Em junho de 2018, a fanpage deste Legislativo excluiu uma publicação no Facebook em que divulgava, citando informações da Polícia Federal, que a maconha poderia levar o usuário à morte. Na postagem intitulada "Os males causados pela maconha", em referência à Semana Nacional Antidrogas, entre os possíveis efeitos imediatos apontados estavam "dificuldade de pensar", "agressividade" e "morte". Já entre os efeitos do uso continuado, a "morte" aparecia novamente, ao lado de "doenças cardiológicas", "pulmonares" e "câncer" (CARVALHO, 2018). O post provocou polêmica nas redes sociais, sendo que a maioria dos comentários questionava a falta de rigor científico das informações e a abordagem sensacionalista do Senado.

Quando o conteúdo controverso foi excluído, a publicação já contava com $50 \mathrm{mil}$ compartilhamentos e mais 21 mil comentários feitos. Ao apagar o post, o Senado informou que havia buscado apoio em material preparado pela Academia Nacional da Polícia Federal sobre o assunto e que, diante da repercussão negativa, optou pela retirada do material das redes sociais. O episódio ilustra como o Senado, por meio de sua comunicação legislativa, pode divulgar informações imprecisas ou manipuladas, a fim de atender os interesses dos agentes políticos que dirigem este parlamento.

Nesse contexto de crescente desconfiança dos cidadãos brasileiros em relação a instituições públicas (MOISÉS, 2010), o Senado tenta responder tratando o tema da desinformação como problema público, ou seja, como objeto que requer a ação do Estado, e tem

\footnotetext{
${ }^{6}$ Disponível em https://www.facebook.com/643992795641315/posts/2082914131749167/. Acesso em: 25 jul. 2019.
} 
sua principal fonte nos acontecimentos da atualidade. Na próxima seção, veremos que o Senado vem discutindo estratégias para combater a propagação de informações falsas, tanto na esfera institucional/comunicacional quanto na legislativa.

\section{Esfera institucional/comunicacional}

Numa tentativa de se fortalecer como uma instituição democrática, republicana e digna de confiança, o Senado desenvolveu algumas ações na esfera institucional no ano passado para discutir o problema da desinformação, privilegiando estratégias de comunicação legislativa, que conferem maior visibilidade aos propósitos deste parlamento.

Em 10 de junho de 2019, no lançamento da campanha contra a desinformação, o presidente do Senado, Davi Alcolumbre, comentou que a iniciativa se tratava de uma ferramenta de gestão democrática: "Na guerra contra as notícias falsas, que são maldosamente criadas para confundir a opinião pública, o Senado está fazendo sua parte" (BRASIL, 2019c). Já a diretora da Secretaria de Comunicação Social do Senado, Angela Brandão, destacou que o cidadão pode ser um parceiro no controle da disseminação de mentiras. Segundo a gestora, quanto mais pessoas souberem como detectar uma notícia falsa, menos ela se espalhará.

As peças publicitárias referentes à campanha contra a desinformação foram publicadas nos produtos da Agência Senado - portal Senado Notícias e no Jornal do Senado - e veiculadas na Rádio Senado e na TV Senado ao longo de suas programações. As plataformas digitais (Facebook, Twitter e Instagram) da Casa também divulgaram as peças, que possuem um caráter de serviço de utilidade pública, com orientações acerca de como identificar um conteúdo falso ou deliberadamente distorcido.

A peça publicitária veiculada no Jornal do Senado (figura 2), na edição de 10 de junho de 2019, além do slogan da campanha, a publicação apresenta cindo passos para que o cidadão não seja enganado por notícias falsas. A peça traz ainda o seguinte alerta "antes de compartilhar uma notícia duvidosa sobre o Senado, descubra o que o Jornal do Senado tem a dizer sobre o assunto", numa tentativa de reforçar a credibilidade do próprio veículo de comunicação institucional da Casa. 
Figura 2 - Edição do Jornal do Senado (10/07/2019)

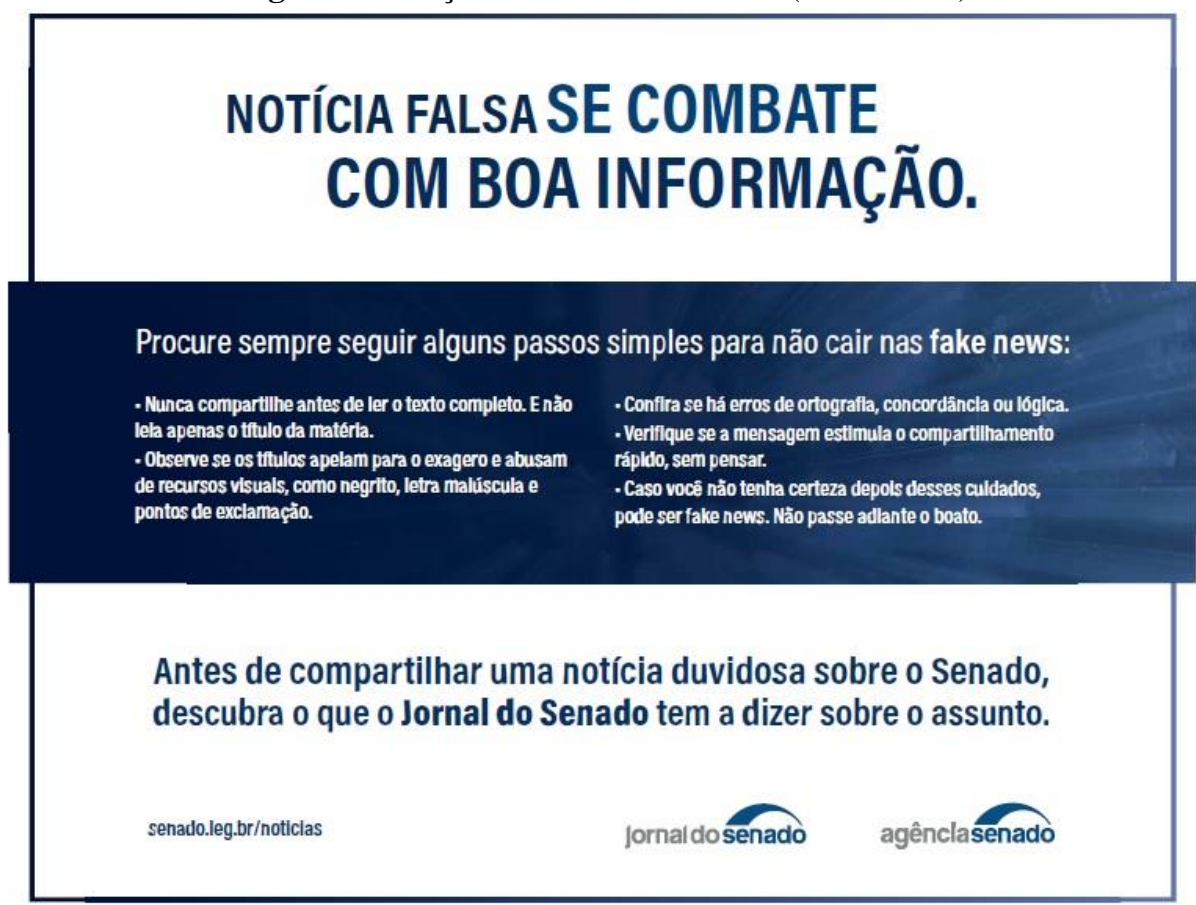

Fonte: Jornal do Senado

Já nas vinhetas da campanha, veiculadas durante a programação da TV Senado e nas redes sociais deste parlamento, os próprios jornalistas do Senado Federal participam das peças, explicando sobre a natureza das notícias falsas e como a sociedade pode combatê-las. Em linhas gerais, a campanha enfoca na ideia de que é possível identificar notícias falsas em circulação nas redes sociais, sendo que uma das possibilidades é o cidadão comum acompanhar o noticiário produzido pelas mídias legislativas do Senado.

A campanha sugere que as mídias do Congresso Nacional são fontes de informação confiáveis para verificar notícias sobre projetos, votações, audiências públicas, e o cotidiano parlamentar de senadores e deputados ("Sabe qual é a melhor maneira de se evitar uma notícia falsa? Ir atrás das fontes oficiais. Nós estamos aqui nos corredores do senado todos os dias"). Com isso, o Senado tenta fortalecer a imagem da comunicação legislativa junto à população como aquela capaz de oferecer uma cobertura jornalística ampla e imparcial acerca dos acontecimentos políticos.

É interessante observar que, em uma das vinhetas, os jornalistas da TV Senado reforçam a ideia de que estão cumprindo seu papel de combater fraudes informativas ("A gente vai seguir fazendo a nossa parte"), mas que é preciso que o cidadão comum também se mobilize na tarefa de não compartilhar conteúdo falso. Para isso, uma das propagandas menciona uma série de procedimentos que servem para identificar uma notícia mentirosa, como: prestar atenção no texto, verificando se tem problema de ortografia e se está bem escrito; desconfiar de manchetes sensacionalistas ou daquelas mensagens que te estimulam a compartilhar rapidamente sem 
criticidade; e pesquisar em outros meios de comunicação, observando se outro órgão de imprensa divulgou a notícia. As vinhetas ressaltam que se o indivíduo não tiver certeza acerca da veracidade de um determinado conteúdo, não deve passá-lo adiante.

Além da campanha institucional contra as fake news, a página do Senado no Facebook desde 2013 publica conteúdos informativos sobre a propagação de desinformação ${ }^{7}$, sendo que a maioria desses posts apresenta caráter educativo, em que se busca conscientizar as pessoas sobre os efeitos perniciosos das informações falsas para a vida em sociedade. As demais publicações têm como objetivo principal desmentir alguma informação falsa sobre o Senado e seus membros. Por ser um dos canais de comunicação do Poder Público com maior alcance do Brasil, a fanpage do Senado tem potencial para atingir um grande número de usuários na internet e, assim, contribuir para elevar o conhecimento das pessoas acerca do fenômeno da desinformação.

Numa análise geral sobre as estratégias de comunicação do Senado, podemos asseverar que a escolha do slogan da campanha institucional ("Notícia falsa se combate com boa informação") superdimensiona o papel do jornalismo, ao sugerir que os efeitos de conteúdos fraudulentos colocados em circulação na internet podem ser neutralizados ou banidos por informação verificada e de qualidade. Nesse aspecto, cabe refletir, a partir do conteúdo publicado pelo Senado, quais veículos de imprensa pretensamente produzem um "bom jornalismo" e, consequentemente, "boa informação". Seriam os meios de comunicação tradicionais ou as próprias mídias legislativas do Congresso?

A corrosão do jornalismo tradicional, fruto da desintermediação comunicacional e da campanha negativa promovida por alguns grupos políticos, se impõe como um desafio às mídias do parlamento, uma vez que historicamente estão associadas ao "chapabranquismo" e à promoção pessoal de seus representantes.

\section{Esfera legislativa}

No Congresso Nacional, tramitam alguns projetos relacionados ao problema da distribuição deliberada de desinformação e do uso irregular de dados pessoais por plataformas digitais. As matérias diferem em relação a que legislação seria alterada para receber o novo tipo de crime. Há propostas que adicionam incisos no Código Penal, no Código de Defesa do Consumidor, no Código Eleitoral e no Marco Civil da Internet (figura 3).

\footnotetext{
${ }^{7}$ Em tese de doutorado em andamento, o autor do presente artigo vem estudando as publicações da fanpage do Senado que versam sobre o problema da desinformação de 2013 a 2019.
} 
Figura 3 - Relação de proposições que versam sobre o combate às fake news

\begin{tabular}{|c|c|c|}
\hline $\begin{array}{c}\text { Lei n }^{0} \text { 12.965/2014 (Marco } \\
\text { Civil da Internet - MCI) }\end{array}$ & Legislação eleitoral & Matéria Criminal \\
\hline $\begin{array}{l}\text { - PLS } 471 / 2018 \\
\text { - PLS 533/2018 } \\
\text { - PL 7604/2017 (temática do MCI, } \\
\text { não modifica lei) }\end{array}$ & $\begin{array}{l}\text { - PLS } 471 / 2018 \\
\text { - PL } 533 / 2018 \\
\text { - PL 2601/2019 } \\
\text { - PL } 9626 / 2018 \\
\text { - PL } 9973 / 2018 \\
\text { - PLS } 218 / 2018 \\
\text { - PL } 9532 / 2018 \text { (apensado ao PL } \\
\text { 5742/2015, que trata sobre } \\
\text { propaganda enganosa) } \\
\text { - PL 11004/2018, PL 10915/2018 e } \\
\text { PL 10292/2018 (apensados ao PL } \\
\text { 9532/2018) }\end{array}$ & 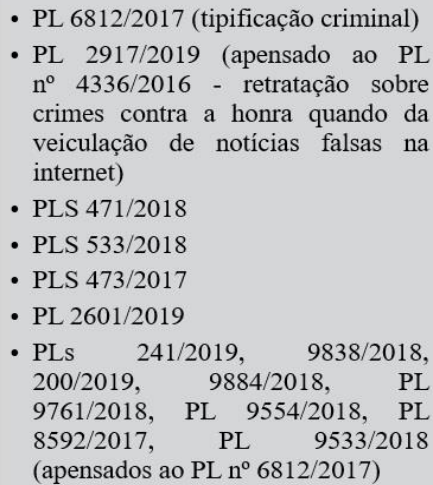 \\
\hline
\end{tabular}

Fonte: Grigori (2018)

Entre as iniciativas legislativas, está o PLS (projeto de lei do Senado) No 473/2017, de autoria do senador Ciro Nogueira (PP-PI), que está em análise na Comissão de Constituição, Justiça e Cidadania (CCJ), sob a relatoria do senador Rodrigo Pacheco (DEM-MG). A proposição altera o Decreto-Lei no 2.848, de 7 de dezembro de 1940 - Código Penal -para tipificar o crime de divulgação de notícia falsa (BRASIL, 2017a). A matéria prevê sanções para quem tem consciência que determinada notícia é falsa e que pode distorcer, alterar ou corromper a verdade sobre informações relacionadas à saúde, à segurança pública, à economia nacional, ao processo eleitoral ou que afetem interesse público relevante.

O mencionado projeto prevê detenção, de seis meses a dois anos, e multa, se o fato não constitui crime mais grave. Se o agente pratica a conduta valendo-se da internet ou de outro meio que facilite a divulgação da notícia falsa sofrerá reclusão, de um a três anos, e multa, se o fato não constitui crime mais grave. A pena aumenta-se de um a dois terços, se o agente divulga a notícia falsa visando a obtenção de vantagem para si ou para outras pessoas.

$\mathrm{Na}$ justificativa do projeto, o parlamentar menciona que quando a vítima pode ser identificada, a divulgação de notícias falsas, via de regra, configura crime contra a honra (calúnia, injúria ou difamação). Porém, existem situações, em que embora o dano não possa ser individualizado, o direito difuso de a população receber notícias verdadeiras e não corrompidas é atingido. Conforme a mencionada matéria legislativa, ocorre que para estes casos a lei penal não prevê qualquer tipo de punição. Dessa maneira, a iniciativa busca criminalizar a divulgação de notícia falsa em que a vítima é a sociedade como um todo. O senador, na justificativa da proposição, entende que o PLS No 473/2017 contribuirá para reprimir e prevenir a divulgação das fake news. 
O projeto PLS $N^{\circ} 473 / 2017$, assim como todas as propostas que tramitam no Senado, foi submetido à consulta pública por meio do portal e-Cidadania ${ }^{8}$. Até o presente momento, 14 de março de 2020 às $11 \mathrm{~h} 57$, foram contabilizados 51.448 votos, sendo 17.374 a favor e 34.074 contra, conforme a figura 5. Apesar de não terem caráter deliberativo, ou seja, não produzem efeito direto em decisões legislativas, as enquetes promovidas pelo Senado sinalizam se determinada iniciativa parlamentar tem respaldo ou não junto a certos setores da sociedade civil.

Figura 4 - Consulta Pública sobre o projeto de lei do Senado Nº 473/2017

\section{LOCONSULTA PÚBLICA}

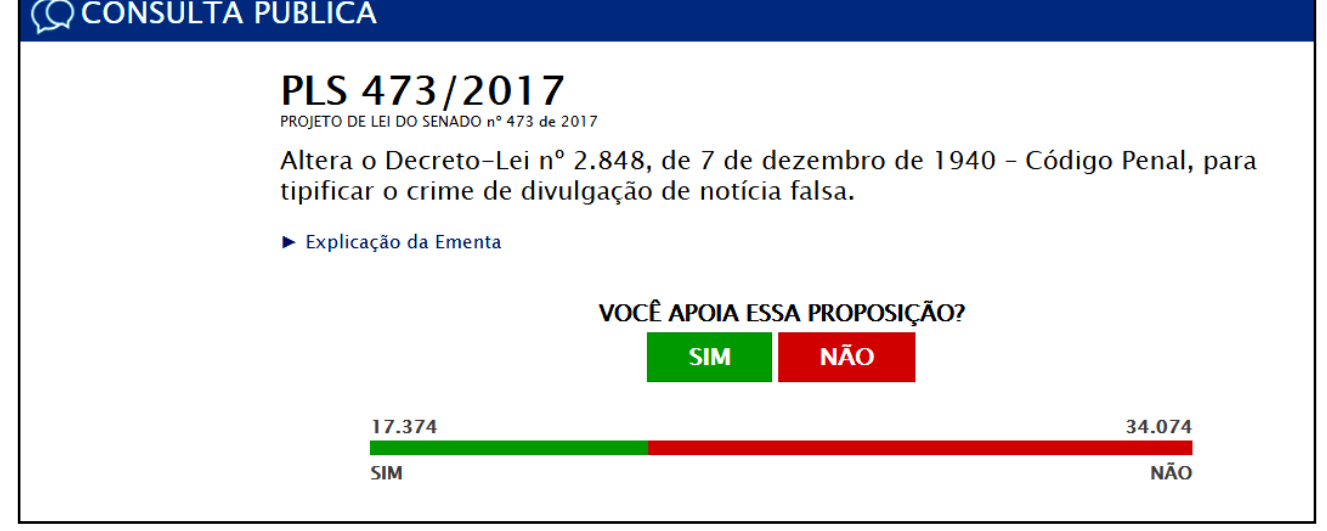

Fonte: Cópia da tela do programa E-cidadania

Existem outras iniciativas parlamentares no Senado contra a disseminação intencional de conteúdo inverídico. O PLS No 413/2017, do senador Eduardo Braga (MDB-AM), pune como crime o uso de robôs que se passam por pessoas reais na internet e enviam mensagens automáticas para influenciar debates políticos ou interferir no processo eleitoral (BRASIL, 2017b). Já o PLS n 218/2018, do ex-senador Antônio Carlos Valadares (PSB/SE), altera a Lei $\mathrm{n}^{\mathrm{o}}$ 9.504/1997, que estabelece normas para as eleições, para estabelecer que a propaganda institucional promovida pelo TSE nos anos eleitorais esclarece sobre a disseminação de informações e notícias falsas, advertindo para as sanções decorrentes de sua divulgação (BRASIL, 2018a).

O PLS n 533/2018, do ex-senador Ataídes Oliveira (PSDB/TO), altera o Código Penal, Código Eleitoral e o Marco Civil da Internet, e prevê detenção, de seis meses a dois anos, e multa, para quem criar ou divulgar notícia que sabe ser falsa para distorcer, alterar ou corromper gravemente a verdade sobre tema relacionado à saúde, à segurança pública, à economia nacional ou a outro interesse público relevante (BRASIL, 2018b). A proposta ainda imputa detenção, de seis meses a três anos, e multa, para quem criar ou divulgar notícia falsa para afetar indevidamente o processo eleitoral.

8 Disponível em: https://www12.senado.leg.br/ecidadania/visualizacaomateria?id=131758\&utm source=midias- 
Temos ainda o PLS $\mathrm{n}^{\circ}$ 471/2018, do senador Humberto Costa (PT/PE), trata da definição das infrações penal, eleitoral e civil de criar ou divulgar notícia falsa (BRASIL, 2018c). E, por fim, tramita no Senado a Sugestão No 246/2018, apresentada dentro do projeto Jovem Senador, que prevê punição aos provedores que descumprirem ordem judicial para retirar conteúdo falso (BRASIL, 2018d). Ambas proposições se encontram, até o presente momento, na Comissão de Constituição, Justiça e Cidadania.

Todas essas proposições apresentadas no Senado impõem, de alguma maneira, restrições legais para combater a desinformação, mas tais projetos de criminalização e responsabilidade pela difusão de informações falsas podem representar um prejuízo ao direito à liberdade de expressão individual, ao estabelecer uma espécie de censura prévia, um mecanismo lesivo ao funcionamento do Estado Democrático de Direito. Por outro lado, os indivíduos têm o direito de serem informados por notícias checadas a partir de critérios jornalísticos consagrados. Quem produz e compartilha, de forma deliberada, conteúdo fraudulento ou impreciso, acaba solapando o ideal democrático, ao deteriorar o ambiente informacional e, consequentemente o debate público.

Frente ao problema público da desinformação, observamos que o Senado, no âmbito legislativo, optou por respostas simplistas e imediatistas, que não são fruto de ampla discussão na sociedade civil. Os projetos apresentados neste legislativo não propõem medidas preventivas para minimizar os impactos da propagação de notícias falsas. A educação midiática (media literacy), por exemplo, pode funcionar como elemento imunizador contra as fake news, ao empoderar os usuários a identificar fontes, gêneros textuais, notícias falsas, e os vieses da mídia, além de possibilitar que os indivíduos pesquisem e utilizem as redes sociais com ética, criatividade e espírito cívico (SAYAD, 2019).

\section{Apontamentos Finais}

A desinformação, enquanto um problema social exige a discussão pública entre diferentes atores institucionais e uma consequente ação governamental. Como observamos neste trabalho, o Senado Federal confere visibilidade ao combate das notícias falsas, colocando-o na ordem do dia das preocupações do Congresso.

Verificou-se que as estratégias adotadas pelo Senado no campo institucional refletem a multidimensionalidade da comunicação legislativa (pública, institucional e política), em que o parlamento agenda determinado tema no debate público, ao mesmo tempo em que busca fortalecer sua imagem institucional e tenta convencer a população sobre a "nobreza" de suas intenções ao privilegiar o combate às fake news. 
A crise de credibilidade na comunicação legislativa, associada ao cenário de desordem informacional e de polarização radicalizada, faz com que boa parte da sociedade não enxergue o Senado como uma instituição capaz de conscientizar a população acerca dos danos causados por mentiras revestidas de atributos que lhe dão aparência de verdade. Nesse sentido, a campanha institucional contra as fake news promovida pelo Senado, apesar de seu caráter normativo e educativo, carece de respaldo junto à população.

Com relação às proposições em discussão no Senado, verifica-se um açodamento em dar respostas rápidas à opinião pública. A desinformação é um problema público amplo, cabendo mobilizar diferentes setores da sociedade civil para compreender como conteúdos fraudulentos se espalham e impactam na vida cotidiana. Considerando que a difusão de informações falsas tira proveito do ambiente político polarizado, seus danos perniciosos no debate público e na arena decisória exigem um maior conhecimento das motivações por trás desse expediente farsesco. Ainda no campo legislativo, devemos pensar em estratégias que contribuam para um ambiente plural e diverso, com diferentes fontes de informação disponíveis aos cidadãos, em que se respeite tanto a liberdade de expressão quanto a proteção à intimidade, à honra e à imagem das pessoas.

Mesmo que o Poder Executivo tenha forte controle sobre a agenda legislativa, reduzindo o raio de ação do Senado, é possível que este parlamento contrarie essa dinâmica e seja responsável por inputs no processo de elaboração de políticas públicas, como no caso de estratégias contra a desinformação. Ao protagonizar o debate público em torno de medidas que combatam a produção e o compartilhamento de conteúdo falso, o Senado tenta ser responsável pela efetivação de ações públicas na prática. Todavia, tais medidas terão maiores chances de serem concretizadas se as negociações políticas com o Poder Executivo estiverem adiantadas, do contrário, o processo pode se alongar ou a proposição sofrer veto do governo ${ }^{9}$.

Temos ainda um longo itinerário para percorrer no sentido de compreender melhor a dinâmica da desinformação. Na medida em que o fluxo de dados e informações é cada vez mais rápido e a distinção entre verdade e mentira cada vez mais frágil, torna-se fundamental a discussão sobre políticas públicas de diminuição de danos em relação à propagação de informações falsas ou deturpadas com fins escusos. Quando falamos sobre esse fenômeno comunicacional, não podemos pensá-lo como algo isolado da cultura política de uma determinada sociedade. Isso não significa que países com instituições democráticas mais sólidas e culturas cívicas robustas estejam imunes à ameaça da desinformação, mas a desconfiança nos Poderes que constituem o Estado favorece o surgimento de teorias conspiratórias e a propagação

\footnotetext{
${ }^{9}$ Em 11 de novembro de 2019, o presidente Jair Bolsonaro sancionou um trecho da Lei 13.834, de 2019, que pune com dois a oito anos de prisão quem divulgar notícias falsas com finalidade eleitoral. A lei havia sido sancionada originalmente em junho, mas um veto parcial deixou de fora o dispositivo que tipifica como crime a disseminação de fake news nas eleições. O veto foi derrubado pelo Congresso em agosto, o que acabou determinando a atualização da norma.
} 
de engodos.

\section{Referências}

ABRANCHES, S. Polarização radicalizada e ruptura eleitoral. In: ABRANCHES, S. et al. (org.). Democracia Em Risco? 22 ensaios sobre o Brasil hoje. São Paulo: Companhia das Letras, 2019. p. 150-167.

ALLCOTT, H.; GENTZKOW, M. Social Media and Fake News in the 2016 Election. Journal of Economic Perspectives, [s.l.], v. 31, n. 2, p. 211-236, 2017. Disponível em: https://www.aeaweb.org/articles?id=10.1257/jep.31.2.211. Acesso em: 18 fev. 2020.

ANDERSON, J. E. Public Policymaking. 7. ed. Boston: Wadsworth-Cengage Learning, 2011. AYMANNS, C.; FOERSTER, J.; GEORG, C.P. Fake News in Social Networks. ArXiv preprint arXiv:1708.06233, [s.l.], 2017. Disponível em: https://arxiv.org/pdf/1708.06233.pdf. Acesso em: 18 fev. 2020.

BENNETT, W. L.; LIVINGSTON, S. The disinformation order: Disruptive communication and the decline of democratic institutions. European journal of communication, [s.l.], v. 33, n. 2, p. 122-139, 2018. Disponível em:

https://www.researchgate.net/publication/324193884_The_disinformation_order_Disruptive_co mmunication_and_the_decline_of_democratic_institutions. Acesso em: 10 jan. 2020.

BOUNEGRU, L.; GRAY, J.; VENTURINI, T.; MAURI, M. A field to guide to fake news - A collection of recipes for those who love to cook with digital methods. [s.l: s.n.]. Disponível em: http://fakenews.publicdatalab.org. Acesso em: 13 mar. 2020.

BRASIL. Senado Federal. Notícia falsa envolvendo TV Senado volta a circular no WhatsApp. Brasília: Senado Federal, 2019b. Disponível em: https://www12.senado.leg.br/noticias/materias/2019/09/30/noticia-falsa-envolvendo-tv-senadovolta-a-circular-no-whatsapp. Acesso em: 13 mar. 2020.

BRASIL. Senado Federal. Projeto de Lei do Senado $n^{\circ}$ 473, de 2017. Altera o Decreto-Lei $\mathrm{n}^{\circ}$ 2.848, de 7 de dezembro de 1940 - Código Penal, para tipificar o crime de divulgação de notícia falsa. Brasília: Senado Federal, 2017a. Disponível em: https://www25.senado.leg.br/web/atividade/materias/-/materia/131758. Acesso em: $18 \mathrm{fev}$. 2020.

BRASIL. Senado Federal. Projeto de Lei do Senado $n^{\circ}$ 413, de 2017. Altera a Lei $n^{\circ} 9.504$, de 30 de setembro de 1997, que estabelece normas para as eleições, para definir como crime a oferta, a contratação ou a utilização de ferramenta automatizada que simule ou possa ser confundida com pessoa natural para gerar mensagens ou outras interações, pela internet ou por outras redes de comunicação, com o objetivo de influenciar o debate político ou de interferir no processo eleitoral. Brasília: Senado Federal, 2017b. Disponível em: https://www25.senado.leg.br/web/atividade/materias/-/materia/131368. Acesso em: 18 fev. 2020. 
BRASIL. Senado Federal. Projeto de Lei do Senado n ${ }^{\circ}$ 218, 2018. Altera a Lei $n^{\circ} 9.504$, de 30 de setembro de 1997, que estabelece normas para as eleições, para determinar que a propaganda institucional do Tribunal Superior Eleitoral contemple advertência sobre notícias falsas. Brasília: Senado Federal, 2018a. Disponível em: https://www25.senado.leg.br/web/atividade/materias/-/materia/133125. Acesso em: 18 fev. 2020 .

BRASIL. Senado Federal. Projeto de Lei do Senado ${ }^{\circ}$ 533, de 2018. Altera o Decreto-Lei ${ }^{\circ}$ 2.848, de 7 de dezembro de 1940 (Código Penal), a Lei no 4.737, de 15 de julho de 1965 (Código Eleitoral), e a Lei no 12.965, de 23 de abril de 2014 (Marco Civil da Internet), para dispor sobre a definição das infrações penal, eleitoral e civil de criar ou divulgar notícia falsa, e cominar as respectivas penas. Brasília: Senado Federal, 2018b. Disponível em: https://www25.senado.leg.br/web/atividade/materias/-/materia/134952. Acesso em: 18 fev. 2020.

BRASIL. Senado Federal. Projeto de Lei do Senado $\mathbf{n}^{\circ}$ 471, de 2018. Altera o Decreto-Lei $\mathrm{n}^{\circ}$ 2.848, de 7 de dezembro de 1940, a Lei $\mathrm{n}^{\circ} 4.737$, de 15 de julho de 1965, e a Lei $\mathrm{n}^{\circ} 12.965$, de 23 de abril de 2014, para dispor sobre a definição das infrações penal, eleitoral e civil de criar ou divulgar notícia falsa, e cominar as respectivas penas. Brasília: Senado Federal, 2018c. Disponível em: https://www25.senado.leg.br/web/atividade/materias/-/materia/134781. Acesso em: 18 fev. 2020.

BRASIL. Senado Federal. Projeto de Lei do Senado $\mathbf{n}^{\circ}$ 246, de 2018. Acrescenta dispositivos à Lei ${ }^{\circ}$ 12.965, de 23 de abril de 2014 (Marco Civil da Internet), que estabelece princípios, garantias, direitos e deveres para o uso da Internet no Brasil, para dispor sobre medidas de combate à divulgação de conteúdos falsos (fake news) ou ofensivos em aplicações de internet. Brasília: Senado Federal, 2018d. Disponível em: https://www25.senado.leg.br/web/atividade/materias/-/materia/133353. Acesso em: 18 fev. 2020.

BRASIL. Senado Federal. Redes Sociais, Notícias Falsas e Privacidade de Dados na Internet: mais de $80 \%$ dos brasileiros acreditam que redes sociais influenciam muito a opinião das pessoas. Brasília: Senado Federal, 2019a. Disponível em:

https://www12.senado.leg.br/institucional/datasenado/publicacaodatasenado?id=mais-de-80dos-brasileiros-acreditam-que-redes-sociais-influenciam-muito-a-opiniao-das-pessoas. Acesso em: 18 fev. 2020.

BRASIL. Senado Federal. Senado faz campanha de combate a notícias falsas. Brasília: Senado Federal, 2019b. Disponível em:

https://www12.senado.leg.br/noticias/materias/2019/06/11/senado-faz-campanha-de-combate-anoticias-falsas. Acesso em: 10 jan. 2020.

CAPELlA, A. C. N. Agenda-Setting. In: DI GIOVANNI, G.; NOGUEIRA, M. A. (org.). Dicionário de Políticas Públicas. São Paulo: Imprensa Oficial; FUNDAP, 2013.

CAPELLA, A. C. N. Formulação de Políticas. Brasília: Enap, 2018.

CARVALHO, M. Os dilemas da comunicação pública na era das redes sociais. Porto Alegre: OBCOMP, 2018. Disponível em: http://www.ufrgs.br/obcomp/textosopinioes/0/628/michel-carvalho--os-dilemas-da-comunicacao-publica-na-era-das-redes-sociais/. Acesso em: 5 jan. 19.

CASTELLS, M. O poder da comunicação. 4. ed. Rio de Janeiro: Paz e Terra, 2019. 
CHESNEY, R.; CITRON, D. K. Deep fakes: a looming challenge for privacy, democracy, and national security. SSRN Electronic Journal, Amsterdam, n. 41, p. 1-68, 2018. Disponível em: https://dx.doi.org/10.2139/ssrn.3213954. Acesso em: 18 fev. 2020.

DARNTON, R. A verdadeira história das notícias falsas: Séculos antes das redes sociais, os boatos e as mentiras alimentavam pasquins e gazetas na Europa. El País, Madrid, 2017. Disponível em: https://brasil.elpais.com/brasil/2017/04/28/cultura/1493389536_863123.html. Acesso em: 16 fev. 2020.

FERRARI, P. Como sair das bolhas. São Paulo: Educ, 2018.

GOMIDE, S. Polícia investiga autoria de notícia falsa sobre o Senado. Brasília: Senado Federal, 2013. Disponível em: https://www12.senado.leg.br/noticias/materias/2013/05/16/policia-investiga-autoria-de-noticiafalsa-sobre-o-senado. Acesso em: 10 jun. 19.

GRAGNANI, J. Um Brasil dividido e movido a notícias falsas: uma semana dentro de 272 grupos políticos no WhatsApp. BBC News Brasil, Londres, 2018. Disponível em: https://www.bbc.com/portuguese/brasil-45666742. Acesso em: 13 mar. 2020.

GRIGORI, P. 20 projetos de lei no Congresso pretendem criminalizar fake news. Agência Pública, São Paulo, maio 2018. Disponível em: https://apublica.org/2018/05/20-projetos-de-leino-congresso-pretendem-criminalizar-fake-news/. Acesso em: 8 jan. 2020.

HOGWOOD, B. W.; GUNN, L. A. Policy analysis for the real world. Oxford: Oxford University Press, 1984.

HOWLETT, M. A dialética da opinião pública: efeitos recíprocos da política pública e da opinião pública em sociedades democráticas contemporâneas. Opinião Pública, Campinas, v. 6, n. 2, p. 167-186, 2000. Disponível em: https://doi.org/10.1590/S0104-62762000000200001. Acesso em: 8 jan. 2020.

KEEN, A. Vertigem digital: por que as redes sociais estão nos dividindo, diminuindo e desorientando. Rio de Janeiro: Zahar, 2012.

KINGDON, J. Agendas, alternatives, and public policies. 3. ed. New York: Harper Collins, 2003.

McCOMBS, M. A Teoria da Agenda: a mídia e a opinião. Petrópolis: Vozes, 2009.

MELLO, P. Empresários bancam campanha contra o PT pelo WhatsApp: com contratos de R \$ 12 milhões, prática viola a lei por ser doação não declarada. Folha de S. Paulo, São Paulo, 2018. Disponível em: https://www1.folha.uol.com.br/poder/2018/10/empresarios-bancamcampanha-contra-o-pt-pelo-

whatsapp.shtml?utm_source=twitter\&utm_medium=social\&utm_campaign=twfolha. Acesso em: 13 mar. 2020.

MIGUEL, L. F. Os meios de comunicação e a prática política. Lua Nova, São Paulo, n. 55-56, p. 155-184, 2002. Disponível em: https://doi.org/10.1590/S0102-64452002000100007. Acesso em: 13 mar. 2020.

MOISÉS, J. A. Cultura política, instituições e democracia: lições da experiência brasileira. In: MOISÉS, J. A. (org.). Democracia e confiança: por que os cidadãos desconfiam das instituições públicas? São Paulo: Edusp, 2010. 
MOROZOV, E. Big tech: a ascensão dos dados e a morte da política. São Paulo: Ubu, 2018. PARISER, E. O filtro invisível: o que a internet está escondendo de você. Rio de Janeiro: Zahar, 2012.

PENTEADO, C. L. C.; FORTUNATO, I. Mídia e políticas públicas: possíveis campos exploratórios. Revista Brasileira de Ciências Sociais, São Paulo, v. 30, n. 87, p. 129-141, 2015. Disponível em: https://doi.org/10.17666/3087129-141/2015. Acesso em: 13 mar. 2020.

RIBEIRO, A. O caso da Escola Base. São Paulo: Ática, 2000.

SASTRE, A.; OLIVEIRA, C. S. P. de; BELDA, F. R. A influência do "filtro bolha" na difusão de Fake News nas mídias sociais: reflexões sobre as mudanças nos algoritmos do Facebook. Revista GEMInIS, São Carlos, v. 9, n. 1, p. 4-17, jan./abr. 2018. Disponível em: https://doi.org/10.4322/2179-1465.0901001. Acesso em: 13 mar. 2020.

SAYAD, A. Idade Mídia: uma idade média às avessas. In: BARBOSA, M. (org.). Pós-verdade e Fake News: reflexões sobre a guerra de narrativas. Rio de Janeiro: Cobogó, 2019.

SILVERSTONE, R. Por que estudar a mídia? São Paulo: Edições Loyola, 2005.

VARGO, C.; GUO, L.; AMAZEEN, A. The Agenda-Setting Power of Fake News: A Big Data Analysis of the Online Media Landscape from 2014 to 2016. New Media \& Society, [s.l.], v. 20, n. 5, p. 2028-2049, 2017. Disponível em: https://doi.org/10.1177/1461444817712086.

Acesso em: 13 mar. 2020.

WARDLE, C.; DERAKHSHAN, H. Information disorder: toward an interdisciplinary framework for research and policy-making. Strasbourg: Council of Europe, 27 set. 2017. Disponível: https://rm.coe.int/information-disorder-toward-an-interdisciplinary-framework-forresearc/168076277c. Acesso em: 18 fev. 2018, p. 5-6.

Artigo recebido em: 2019-07-31

Artigo reapresentado em: 2019-09-21

Artigo aceito para publicação em: 2020-03-25 